\title{
Radiochemical Methodologies Applied to Analytical Characterization of Low and Intermediate Level Wastes from Nuclear Power Plants
}

Monteiro $^{a}$ R. P. G., Júnior ${ }^{a}$ A. S. R., Kastner ${ }^{a}$ G. F., Temba ${ }^{a}$ E. S. C., Oliveira ${ }^{a, b}$ T. C., Amaral $^{\text {a }}$ A. M. and Franco ${ }^{\text {a }}$ M. B.

${ }^{a}$ Centro de Desenvolvimento da Tecnologia Nuclear, CDTN/CNEN, 31270-901, Belo Horizonte, Minas Gerais Brazil

${ }^{\text {b }}$ Departamento de Engenharia Nuclear, UFMG/DEN, 31270-901, Belo Horizonte, Minas Gerais, Brazil

rpgm@cdtn.br (Monteiro R. P. G)

\begin{abstract}
The aim of this work is to present radiochemical methodologies developed at CDTN/CNEN in order to answer a program for isotopic inventory of radioactive wastes from Brazilian Nuclear Power Plants. In this program some radionuclides, ${ }^{3} \mathrm{H},{ }^{14} \mathrm{C},{ }^{55} \mathrm{Fe},{ }^{59} \mathrm{Ni},{ }^{63} \mathrm{Ni},{ }^{90} \mathrm{Sr},{ }^{93} \mathrm{Zr},{ }^{94} \mathrm{Nb},{ }^{99} \mathrm{Tc},{ }^{129} \mathrm{I},{ }^{235} \mathrm{U},{ }^{238} \mathrm{U},{ }^{238} \mathrm{Pu},{ }^{239+240} \mathrm{Pu},{ }^{241} \mathrm{Pu},{ }^{242} \mathrm{Pu}$, ${ }^{241} \mathrm{Am},{ }^{242} \mathrm{Cm} \mathrm{e}{ }^{243+244} \mathrm{Cm}$, were determined in Low Level Wastes (LLW) and Intermediate Level Wastes (ILW) and a protocol of analytical methodologies based on radiochemical separation steps and spectrometric and nuclear techniques was stablished.
\end{abstract}

Keywords: Radioactive waste, Radionuclides, Radioanalitycal techniques

ISSN: 2319-0612

Accept Submission: 2018-10-31 


\section{INTRODUCTION}

The long-term risk related to the disposal of radioactive waste produced by PWR (pressurized water reactor) nuclear power plants is determined primarily by the presence of the long lived radionuclides. The control of these radionuclides in waste packages is necessary to insure the respect of waste acceptance criteria that are fixed in order to avoid any potential impact of the radioactive contaminants on the environment of the repository site [1-3].

Several of the radionuclides considered significant are non-gamma-emitting isotopes, consequently are not easily measured by routine techniques employed at most nuclear plants they are termed "difficult to measure" (DTM).

Some years ago our group at CDTN/CNEN (Centro de Desenvolvimento da Tecnologia Nuclear / Comissão Nacional de Energia Nuclear) take a part in a project together with Eletrobrás Termonuclear in order to develop and establish radioanalytical methodologies applied to determination of ${ }^{3} \mathrm{H}$, ${ }^{14} \mathrm{C},{ }^{55} \mathrm{Fe},{ }^{59} \mathrm{Ni},{ }^{63} \mathrm{Ni},{ }^{90} \mathrm{Sr},{ }^{93} \mathrm{Zr},{ }^{94} \mathrm{Nb},{ }^{99} \mathrm{Tc},{ }^{129} \mathrm{I},{ }^{235} \mathrm{U},{ }^{238} \mathrm{U},{ }^{238} \mathrm{Pu},{ }^{239+240} \mathrm{Pu},{ }^{241} \mathrm{Pu},{ }^{242} \mathrm{Pu},{ }^{241} \mathrm{Am},{ }^{242} \mathrm{Cm}$ $\mathrm{e}^{243+244} \mathrm{Cm}$ in intermediate (ILW) and low level (LLW) radioactive wastes samples from Brazilian nuclear power plants.

The aim of this work is to present a review about radiochemical methodologies developed at CDTN/CNEN in order to answer a program for isotopic inventory of radioactive wastes and present new research perspectives covering new methodologies for LLW and ILW characterization. More recently, the number of publications on this topic has been great, involving innovative methodologies and analytical techniques [4-7]. 


\section{MATERIALS AND METHODS}

With the recent advances in the development of extractive resins, selective to a large range of chemical elements and available in the international market, it is now possible to separate a large amount of DTM radionuclides efficiently and with great reduction in analysis times. In addition, other isotopic analytical techniques, such as multi-collector ICP-MS (Inductively coupled plasma mass spectrometry) and TIMS (Thermal Ionization Mass Spectrometry) [8] high resolution mass spectrometry have been successfully applied. The following is a summary of all the methodologies developed and implanted in our laboratory.

\subsection{Sequential analytical methodology}

The first stage of this work was dedicated to the development of an analytical methodology, which comprised the determination of several radionuclides in a sequential form. In this development the radionuclides ${ }^{55} \mathrm{Fe},{ }^{59} \mathrm{Ni},{ }^{63} \mathrm{Ni},{ }^{90} \mathrm{Sr},{ }^{235} \mathrm{U},{ }^{238} \mathrm{U},{ }^{238} \mathrm{Pu},{ }^{239+240} \mathrm{Pu},{ }^{241} \mathrm{Pu},{ }^{242} \mathrm{Pu},{ }^{241} \mathrm{Am},{ }^{242} \mathrm{Cm}$ and ${ }^{243+244} \mathrm{Cm}$ were the purpose of study.

\subsubsection{Uranium and transuranic isotopes determination}

Alpha spectrometry analysis was used for activity determinations of $\mathrm{U}, \mathrm{Pu}, \mathrm{Am}$ and $\mathrm{Cm}$ isotopes using a sequential procedure. The first step was $\mathrm{Pu}$ isolation by an anion exchange column Dowex $1 \times 8$ followed by an Am and $\mathrm{Cm}$ separation of $\mathrm{U}$ and Fe by a co-precipitation with oxalic acid. The precipitate was used for americium and curium separation of strontium by using a TRU resin extraction chromatography column. Due their chemical similarities and energy difference it was seen that the simultaneous determination of ${ }^{241} \mathrm{Am},{ }^{242} \mathrm{Cm}$ and ${ }^{243,244} \mathrm{Cm}$ isotopes is possible using the ${ }^{243} \mathrm{Am}$ as tracer. The $\mathrm{pH}$ of the solution retaining $\mathrm{U}$ and $\mathrm{Fe}$ was corrected for co-precipitation of iron 
hydroxide and uranium. Fe and $U$ were separated by anion exchange column (Dowex $1 \times 8$ ). In this work it was used tracers, ${ }^{238} \mathrm{Pu},{ }^{243} \mathrm{Am},{ }^{244} \mathrm{Cm}$ and ${ }^{232} \mathrm{U}$, for determination and quantification of theirs isotopes, respectively $[9,10]$.

\subsubsection{The ${ }^{55} \mathrm{Fe}$ determination}

The determination of ${ }^{55} \mathrm{Fe}$ was performed by LSC (Liquid Scintillation Spectrometry) and the measurements were carried out after 24 hours in a dark room for stabilization. A standard ${ }^{55} \mathrm{Fe}$ solution of known activity was used to determine the counting efficiency. The background was evaluated by preparing a blank sample with nitric acid solution and Optiphase Hisafe 3 scintillation cocktail $[11,12]$.

\subsubsection{The ${ }^{59} \mathrm{Ni}$ and ${ }^{63} \mathrm{Ni}$ determination}

The radiochemical separation for nickel was performed by anion-exchange chromatography, extraction chromatography, using $\mathrm{Ni}$ resin, and precipitation techniques. Nickel was separated from uranium and iron by co-precipitation of them with ammonium hydroxide. Nickel was purified by $\mathrm{Ni}$ resin and the ${ }^{63} \mathrm{Ni}$ was measured by liquid scintillation counting and the ${ }^{59} \mathrm{Ni}$ by low energy gamma spectrometry. Samples of radioactive wastes such as evaporator concentrate, filter and resin were analyzed. The chemical yield for separation procedure for $\mathrm{Ni}$ is determined with the addition of $\mathrm{Ni}$ as yield monitor and using ICP-AES (Inductively coupled plasma atomic emission spectroscopy) technique for Ni concentration measurements $[11,13]$. 


\subsubsection{The ${ }^{90} \mathrm{Sr}$ determination}

For the separation and purification of strontium the procedure developed was based in methods for analysis of strontium in different matrices. The precipitate containing Am and Sr, from the coprecipitation with oxalic acid and calcium as carrier was dissolved and passed in the column containing TRU Resin. The combined effluents containing Sr were evaporated to dryness on a hotplate. The residue was taken up in nitric acid solution and loaded onto the $\mathrm{Sr}$ resin, previously conditioned. The column was rinsed with a further nitric acid. This time must be recorded as the start of yttrium ingrowth. After some gravimetric steps the final solution was mixed with Optiphase Hisafe 3 scintillation cocktail and immediately counted by LSC $[10,14]$.

\subsection{Methodology for ${ }^{93} \mathrm{Zr}$ determination}

Measurement of ${ }^{93} \mathrm{Zr}$ is difficult owing to its trace level concentration and its low activity in nuclear wastes and further because its certified standards are not frequently available. Two different methodologies based on liquid-liquid extraction with 1-(2-thenoyl)-3,3,3-trifluoroacetone in xylene and back extraction associated with extractive resins TRU and TEVA supplied by Eichrom was carried out in order to separate zirconium. The LSC and ICP-MS techniques were used for ${ }^{93} \mathrm{Zr}$ measurements ILW and LLW wastes samples $[15,16]$.

\subsection{Methodology for ${ }^{94} \mathrm{Nb}$ determination}

For ${ }^{94} \mathrm{Nb}$ determination although it is a strong gamma emitter its concentration in radioactive waste samples are usually several orders of magnitude lower than other interferents $\beta-\gamma$ emitters. The procedure involves extraction chromatography by using TEVA resin to isolate the $\mathrm{Nb}$ nuclide and the gamma spectrometry to its measurement by using a gamma spectrometer with hyper-pure germanium detector. Samples of evaporator concentrate and spent resin were analyzed [17]. 


\subsection{Methodology for ${ }^{99} \mathrm{Tc}$ determination}

A methodology based on separation and purification for technetium was developed in which rhenium was used as a yield monitor. The separation was performed by anion exchange chromatography and extraction chromatography using a TEVA resin. The determination of ${ }^{99} \mathrm{Tc}$ was carried out by LSC and rhenium was activated in the TRIGA Mark 1 research reactor and measured by gamma spectrometry by using a gamma spectrometer with hyper-pure germanium detector [18].

\subsection{Methodology for ${ }^{129}$ I determination}

Two radiochemical procedures for ${ }^{129}$ I determination in low and intermediate level radioactive wastes from nuclear power plants were carried out. The procedures were based on oxidative extraction, alkaline absorption and organic solvent extraction in order to separate iodine from the matrices and activity measurement of ${ }^{129}$ I by ultra-low gamma spectrometry technique. To set up the yield recovery for ${ }^{129} \mathrm{I}$, a tracer solution of ${ }^{131} \mathrm{I}$ was used in order to follow the behavior of iodine during the separation steps. A certified standard for ${ }^{129}$ I from NIST (National Institute of Standards and Technology) was used for ${ }^{129}$ I activity determination in the matrices analyzed [19].

\subsection{Methodology for ${ }^{14} \mathrm{C}$ determination}

In the proposed methodology, the ${ }^{14} \mathrm{C}$ present in the sample is extracted $\mathrm{as}^{\mathrm{CO}}$ by acidification and oxidation. $\mathrm{CO}_{2}$ is absorbed in a alkaline solution, from which an aliquot is taken, which is mixed with a scintillation cocktail. The activity of ${ }^{14} \mathrm{C}$ is determined using the $\mathrm{LSC}[20,21]$. Figure 1 presents the analytical assembly. 
Figure 1: Analytical assembly for ${ }^{14} \mathrm{C}$ analysis

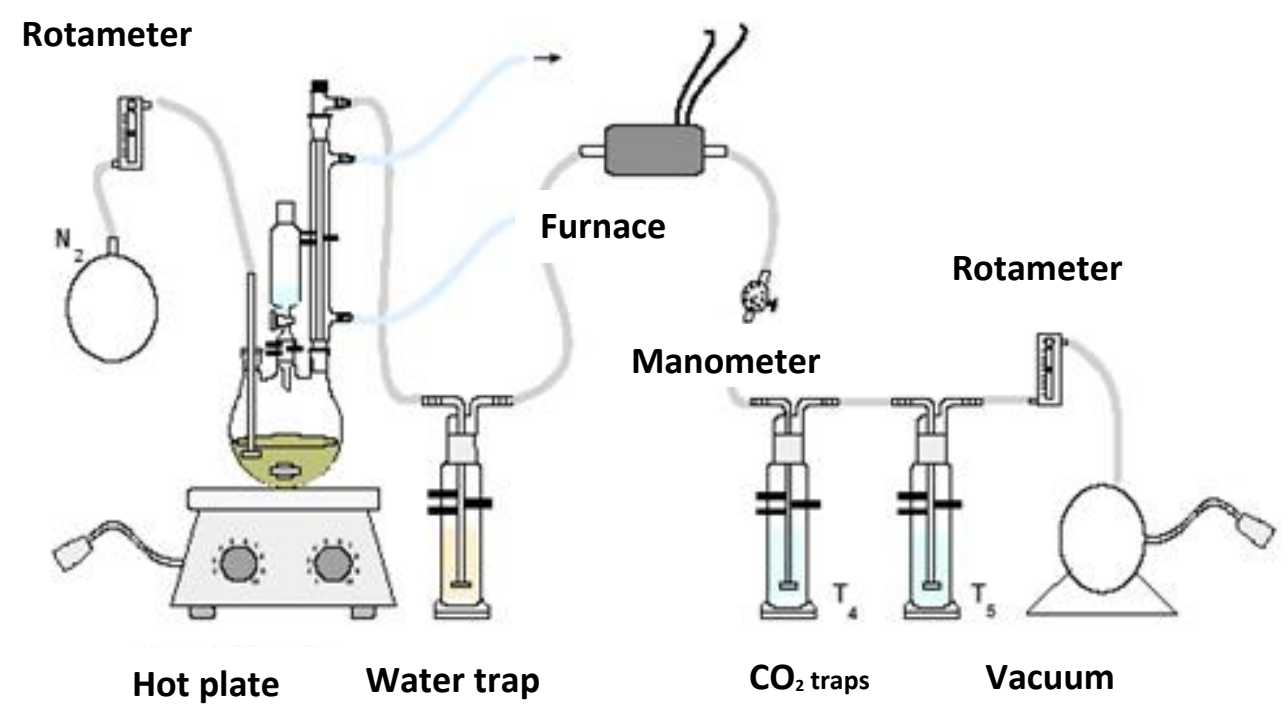

\subsection{Methodology for ${ }^{3} \mathrm{H}$ determination}

The methodology used for the determination of this radionuclide in different matrices consists of the process of separation by distillation [20] and aliquots of LLW and ILW samples were used. A volume of distillate was mixed with Ultima Gold LLT scintillation cocktail and the tritium present was determined by LSC.

\subsection{Methodology for gamma emitters determination}

The specification of the radionuclide inventory can either be achieved by destructive or non-destructive assay (NDA) methods such as segmented $\gamma$-scanning or tomography. Since destructive methods require reopening of containers and also time consuming drilling within their contents the NDA is generally the more preferred method. To estimate the concentrations of DTM nuclides 
indirect measurement methods are proposed and used. The method most commonly used by utilities is the application of scaling factors (SF). This method for the determination of those nuclides in the waste streams produced by a nuclear power reactor consists of applying correction factors between those critical nuclides and so called key nuclides, which can be easily measured and are representative for the occurrence of activation products $\left({ }^{60} \mathrm{Co}\right)$ and fission products $\left({ }^{137} \mathrm{Cs}\right)$ in the waste streams. Scaling factors for DTM can be derived from samples collected frequently from the waste stream, sent to an off-site analytical laboratory for radiochemical analysis and measurement of the radionuclides.

In addition to these key radionuclides, other gamma emitters of large half-lives are present in the wastes and therefore must be determined, for example, ${ }^{54} \mathrm{Mn},{ }^{57} \mathrm{Co},{ }^{58} \mathrm{Co},{ }^{65} \mathrm{Zn},{ }^{110 \mathrm{~m}} \mathrm{Ag},{ }^{124} \mathrm{Sb},{ }^{125} \mathrm{Sb}$ and ${ }^{134} \mathrm{Cs}$, and gamma spectrometry is the traditional technique for this purpose. In our laboratory we used the gamma spectrometer with hyper-pure germanium detector.

\subsection{Limit of Detection determination}

The Lower Limit of Detection (LLD) was determined according to Currie [22] based on equation 1 and used in the different methodologies.

$$
L L D=\frac{2.71+4.66\left(\sigma_{b}\right)}{T . e f f . Y . w t .2 .22}
$$

Were $\sigma_{b}$ is the standard deviation of background counting, $T$ is the time of background counting, eff is the counting efficiency, $Y$ is the chemical yield and $w t$ is the weight of sample. 


\section{RESULTS AND DISCUSSION}

In Table 1, the methodologies and analytical techniques used are presented in a consolidated form, and have been shown to be the most suitable for the radiochemical characterization of LLW and ILW. The LLD for different radionuclides and matrices are reported too in this Table.

Table 1. Methodologies and Techniques for RDMs

\begin{tabular}{|c|c|c|c|c|}
\hline $\mathrm{RDM}$ & Methodology & Technique & $\begin{array}{l}\text { Analytical che- } \\
\text { mical yield }(\%)\end{array}$ & LLD \\
\hline${ }^{3} \mathrm{H}$ & Distillation & LSC & $>90$ & $3.0 \times 10^{-3} \mathrm{~Bq} \cdot \mathrm{g}^{-1}$ \\
\hline${ }^{14} \mathrm{C}$ & $\begin{array}{l}\text { Radiochemical } \\
\text { separation and } \\
\text { solvent extrac- } \\
\text { tion }\end{array}$ & LSC & $>90$ & $4.0 \times 10^{-3} \mathrm{~Bq} \cdot \mathrm{g}^{-1}$ \\
\hline${ }^{55} \mathrm{Fe}$ & $\begin{array}{l}\text { Radiochemical } \\
\text { separation with } \\
\text { TRU resin }\end{array}$ & LSC & $40-100$ & $4.7 \times 10^{-3} \mathrm{~Bq} \cdot \mathrm{g}^{-1}$ \\
\hline${ }^{59} \mathrm{Ni}$ & $\begin{array}{l}\text { Radiochemical } \\
\text { separation with } \\
\text { Ni resin }\end{array}$ & $\begin{array}{l}\text { Low energy } \\
\text { gamma spec- } \\
\text { trometry }\end{array}$ & $60-80$ & $1.1 \times 10^{-3} \mathrm{~Bq} \cdot \mathrm{g}^{-1}$ \\
\hline${ }^{63} \mathrm{Ni}$ & $\begin{array}{l}\text { Radiochemical } \\
\text { separation with } \\
\text { Ni resin }\end{array}$ & LSC & $60-80$ & $1.2 \times 10^{-2} \mathrm{~Bq} \cdot \mathrm{g}^{-1}$ \\
\hline${ }^{90} \mathrm{Sr}$ & $\begin{array}{l}\text { Radiochemical } \\
\text { separation with } \\
\text { Sr resin }\end{array}$ & LSC & $60-90$ & $6.1 \times 10^{-4} \mathrm{~Bq} \cdot \mathrm{g}^{-1}$ \\
\hline${ }^{93} \mathrm{Zr}$ & $\begin{array}{l}\text { Radiochemical } \\
\text { separation with } \\
\text { TRU and TEVA- } \\
\text { resins }\end{array}$ & $\begin{array}{c}\text { LSC } \\
\text { ICPMS }\end{array}$ & 75 & $\begin{array}{l}5.0 \times 10^{-5} \mathrm{~Bq} \cdot \mathrm{g}^{-1} \\
\quad \text { for } \mathrm{LSC} \\
4.5 \times 10^{-5} \mu \mathrm{g} \cdot \mathrm{g}^{-1} \\
\text { for ICP-MS }\end{array}$ \\
\hline
\end{tabular}




\begin{tabular}{|c|c|c|c|c|}
\hline${ }^{94} \mathrm{Nb}$ & $\begin{array}{l}\text { Radiochemical } \\
\text { separation with } \\
\text { TEVA resin }\end{array}$ & $\begin{array}{l}\text { Gamma spec- } \\
\text { trometry }\end{array}$ & 75 & $9.6 \times 10^{-4} \mathrm{~Bq} \cdot \mathrm{g}^{-1}$ \\
\hline${ }^{99} \mathrm{Tc}$ & $\begin{array}{c}\text { Radiochemical } \\
\text { separation with } \\
\text { TEVA-resin }\end{array}$ & LSC & 90 & $3.2 \times 10^{-3} \mathrm{~Bq} \cdot \mathrm{g}^{-1}$ \\
\hline${ }^{129} \mathrm{I}$ & $\begin{array}{l}\text { Radiochemical } \\
\text { separation with } \\
\text { solvent extrac- } \\
\text { tion }\end{array}$ & $\begin{array}{l}\text { Low energy } \\
\text { gamma spec- } \\
\text { trometry }\end{array}$ & 80 & $1.2 \times 10^{-3} \mathrm{~Bq} \cdot \mathrm{g}^{-1}$ \\
\hline $\begin{array}{c}{ }^{235} \mathrm{U},{ }^{238} \mathrm{U},{ }^{238} \mathrm{Pu}, \\
{ }^{239+240} \mathrm{Pu},{ }^{241} \mathrm{Pu}, \\
{ }^{242} \mathrm{Pu},{ }^{241} \mathrm{Am}, \\
{ }^{242} \mathrm{Cm},{ }^{243+244} \mathrm{Cm}\end{array}$ & $\begin{array}{l}\text { Radiochemical } \\
\text { separation with } \\
\text { DOWEX and } \\
\text { TRU resin }\end{array}$ & $\begin{array}{l}\text { Alpha spec- } \\
\text { trometry }\end{array}$ & $>90$ & $2.05 \times 10^{-6} \mathrm{~Bq} \cdot \mathrm{g}^{-}$ \\
\hline
\end{tabular}

\section{CONCLUSION}

The specialized technical literature regarding the analytical methodologies to be used for the determination of these radionuclides is rare and depends on the nuclear power plant type that generates the waste. Adaptations are almost always necessary in methodologies already validated for environmental and geological matrices, where the publication of works is much more frequent. The activity levels and diversity of the radionuclides present in these types of tailings often restrict the direct application of a certain methodology developed for common matrices. It is important to note that few countries have a well-established program for isotopic inventory, among which can be cited France, Japan, Germany and the United States. Brazil's investment in such research opens up prospects for technological interaction with these countries and others still emerging in the theme for the solution of problems of common interest in the nuclear area. Moreover, the establishment of a specific analysis protocol for the radiochemical characterization of tailings is an important contribution to the government's final replacement program for radioactive tailings of low and intermediate activities. 


\section{FUTURE PERSPECTIVES}

Currently, our group continues to work on enhancing the methodologies developed and implementing innovations based on the technological advance of analytical instrumentation and software as well as the use of new materials for high selectivity chemical separations.

In the ICP-MS measurements trace element analysis the most serious complication are often isobaric interferences leading to increased background count rates and degraded detection limits and resolutions. Recent advances using Dynamic Reaction Cells (DRC) in plasma mass spectrometry permits the use of selective ion molecule chemistry for the chemical resolution of isobaric interferences. Choice of reagent gas admitted to the DRC is influenced by the reactivity of that gas towards both the interference ion and the analyte ion. The appropriate choice contributes to the resolution of isobaric overlap by removal of the interference ion. Bandura et al. [23], report examples of ion reactions - molecule in order to eliminate interference isobaric and among these the ${ }^{93} \mathrm{Mo}^{+} /{ }^{93} \mathrm{Nb}^{+} /{ }^{93} \mathrm{Zr}^{+}$ separation using nitrogen oxides for ion-gas reaction.

Despite the promising research in the field of ion-molecule reactions, chemical separations are always needed and especially when working with waste samples from nuclear power due to its very complex chemical and radiochemical characteristics. Ion-molecule reactions may prove to be a final step after the chemical separations for the complete elimination of isobaric interferences.

Recently we are working on advanced stage of development for determination of ${ }^{108 \mathrm{~m}} \mathrm{Ag}\left(\mathrm{t}_{1 / 2}=\right.$ $418 \mathrm{y})$ and ${ }^{135} \mathrm{Cs}\left(\mathrm{t}_{1 / 2}=2.3 \times 10^{6} \mathrm{y}\right)$, two radionuclides of relevant impact in the characterization of LLW and ILW kinds of wastes from NPP for final deposition purposes. The new extractive resins, Cl-resin and AMP-PAN from Eichrom, suitable respectively for the radiochemical separations of these nuclides promise better efficiency and recovery yields as well as reduction of analysis time.

\section{ACKNOWLEDGMENT}


The authors are very grateful to the work supported by the Minas Gerais State FAPEMIG (Fundação de Amparo a Pesquisa do Estado de Minas Gerais).

\section{REFERENCES}

1. Electric Power Research Institute (US) Low-level waste characterization guidelines. Pleasant Hill, EPRI-TR-1072 (1996).

2. IAEA Nuclear Energy Series. Determination and use of scaling factors for waste characteriz ation in nuclear power plants. IAEA, Vienna No. NW-T-1.18 (2009).

3. Environmental Protection Agency (US). Inventory of radiological methodologies; for sites contaminated with radioactive materials. Montgomery: EPA 402-R-06-007 (2006).

4. Silliková V., Dulanská S., "Sequential determination of ${ }^{99} \mathrm{Tc}$ and ${ }^{126} \mathrm{Sn}$ in radioactive concentrate ”, Acta Chimica Slovaca, 10(1), pp. 61-64 (2017), DOI: 10.1515/acs-2017-0010

5. Szabolcs .O et al, "Determination of ${ }^{93} \mathrm{Zr}$ in nuclear power plant wastes", J Radioanal Nucl Ch em 314, pp. 31-38 (2017), DOI 10.1007/s10967-017-5382-z.

6. B. Remenec et al, "Determination of ${ }^{129} \mathrm{I}$ using volatilization method and liquid scintillation spectrometry”, J Radioanal Nucl Chem 311, pp. 1649-1655 (2017), DOI 10.1007/s10967-0165147-0.

7. Dulanska S. et al, "Sequential determination of ${ }^{93} \mathrm{Zr},{ }^{94} \mathrm{Nb},{ }^{99} \mathrm{Tc}$ and ${ }^{126} \mathrm{Sn}$ in radioactive waste us ing anion exchange resin and TEVA_Resin", J Radioanal Nucl Chem 309, pp. 685-689 (2016 ), DOI 10.1007/s10967-015-4613-4.

8. Quemet A., Maillard C., Ruas A., "Determination of zirconium isotope composition and concen tration for nuclear sample analysis using Thermal Ionization Mass Spectrometry”, International Journal of Mass Spectrometry, 392, pp.34-40 (2015). 
9. Reis Jr. A.S., Temba E.S.C., Kastner G.F., Monteiro R.P.G., "Separation and Activity Determ ination of ${ }^{239+240} \mathrm{Pu},{ }^{241} \mathrm{Am}$ and Curium $\left({ }^{242}\right.$ and $\left.{ }^{244} \mathrm{Cm}\right)$ in Evaporator Concentrate by Alpha Spectrometry," Proceeding of International Nuclear Atlantic Conference - INAC 2013, Recife, November 24-29 (2013).

10. Reis Jr. A.S., Temba E.S.C., Kastner G.F., Monteiro R.P.G., "Combined procedure using radioc hemical separation of plutonium, americium and uranium radionuclides for alpha-spectro metry”, Journal of Radioanalytical and Nuclear Chemistry, 287, pp.567-572 (2011).

11. Temba E.S.C., "Separação e determinação radiométrica dos radionuclídeos 59Ni, 63Ni, 55F e, 99Tc e $94 \mathrm{Nb}$ em rejeitos radioativos de baixa e media atividades provenientes de centrai s nucleares do tipo PWR", Tese de Doutorado, CDTN, Belo Horizonte, 2016.

12. Franco M. B. et al, "Chemical yield determination for ${ }^{59} \mathrm{Ni},{ }^{63} \mathrm{Ni}$ and ${ }^{55} \mathrm{Fe}$ in low and interme diate nuclear wastes by ICP-AES", Proceedings of International Nuclear Atlantic Conference - INAC 2011, Belo Horizonte, October 24-28, 2011.

13. Reis Jr. A.S., Temba E.S.C., Kastner G.F., Monteiro R.P.G., Nuclear Power Plants, In Thec, C roatia (2012).

14. Temba E.S.C., Reis Jr. A.S., Amaral A.M., Monteiro R.P.G., "Separation and determination of 9 ${ }^{0} \mathrm{Sr}$ in low- and intermediatelevel radioactive wastes using extraction chromatography and LSC" , Journal of Radioanalytical and Nuclear Chemistry, 290, pp.631-635 (2011).

15. Oliveira T.C., Monteiro R.P.G., Oliveira A.H., “A selective separation method for ${ }^{93} \mathrm{Zr}$ in radioc hemical analysis of low and intermediate level wastes from nuclear power plants", Journal of R adioanalytical and Nuclear Chemistry, 289, pp.497-501 (2011). 
16. Oliveira T.C., Monteiro R.P.G., Kastner G.F., Bessueille-Barbier F., Oliveira A.H., "Radiochemical methodologies applied to determination of zirconium isotopes in low-level waste samples from nuclear power plants", Journal of Radioanalytical and Nuclear Chemistry, 302, pp.4147 (2014).

17. Temba E.S.C., Kastner, G.F., Reis Jr. A.S., Monteiro R.P.G., Moreira R.M., "Determination of ${ }^{94} \mathrm{Nb}$ in radioactive wastes using extraction chromatography and gamma spectrometry”, Journal of Radioanalytical and Nuclear Chemistry, 311, pp.1627-1631 (2017).

18. Temba E.S.C., Reis Jr. A.S., Kastner, G.F., Monteiro R.P.G., Moreira R.M., "Separation and determination of the difficult-to-measureradionuclide ${ }^{99} \mathrm{Tc}$ in radioactive wastes from nuclear power plants by using extraction chromatography and radiometric techniques", Journal of Radioanalytical and Nuclear Chemistry, 307, pp.1453-1458 (2016).

19. Kastner G.F., Oliveira T.C., Monteiro R.P.G., "Radiochemical Determination of ${ }^{129}$ I in Low and Intermediate Nuclear Wastes," Proceeding of International Nuclear Atlantic Conference INAC 2011", Belo Horizonte, October 24-28 (2011).

20. Rodríguez, M. et al. Interlaboratory radiochemical analysis comparison on a primary waste flux. Luxembourg: European Commission, EUR-20616, (2003).

21. Magnusson, $\AA$. et al. " ${ }^{14} \mathrm{C}$ in spent ion-exchange resins and process water from nuclear reactors: A method for quantitative determination of organic and inorganic fractions”, Journal of Radionalytical and Nuclear Chemistry, 275, pp.261-273 (2008).

22. Currie, L.A., "Limits for qualitative detection and quantitative Determination- Application to Ra diochemistry", Analytical Chemistry, 40, pp.586-593 (1968). 
23. Bandura D.R., Baranov V.I., Litherland A.E., Tanner S.D., "Gas-phase ion-molecule reactions $\mathrm{f}$ or resolution of atomic isobars: AMS and ICP-MS perspectives", International Journal of Mas s Spectrometry, 255-256, pp.312-327 (2006). 